\title{
How smart growth and green infrastructure can mutually support each other - A conceptual framework for compact and green cities
}

\author{
Martina Artmann ${ }^{\mathrm{a}, *}$, Manon Kohler ${ }^{\mathrm{a}}$, Gotthard Meinel ${ }^{\mathrm{a}}$, Jing Gan ${ }^{\mathrm{b}}$, Ioan-Cristian Ioja ${ }^{\mathrm{c}}$ \\ ${ }^{a}$ Leibniz Institute of Ecological Urban and Regional Development, Weberplatz 1, Dresden, 01217, Germany \\ b Tongii University, Urban Planning Department, College of Architecture and Urban Planning, 1239 Siping Rd., Shanghai, 200092, China, \\ ${ }^{c}$ University of Bucharest, Centre for Environmental Research and Impact Studies, 1 Bd. Nicolae Balcescu, Sector 5, Bucharest, 010041, Romania
}

\section{A R T I C L E I N F O}

\section{Keywords:}

Urban development

Compact city paradox

Indicators

Social-ecological system

Systemic solutions

Complexity

\begin{abstract}
A B S T R A C T
In contrast to the ongoing worldwide uncontrolled expansion of urban development resulting in sprawled cities, compact cities have been argued by planners and researchers to be the more sustainable urban form. However, in compact cities, it has been shown that a low proportion of green spaces jeopardizes the sufficient supply of urban ecosystem services. This suggests that there remains a deficiency in clear visions for operationalizing compact and green cities. To remediate this, this paper introduces a systemic conceptual framework for compact and green cities by combining the concepts of smart growth and green infrastructure. The indicator-based, smartcompact-green city framework includes two aspects: 1) smart compact cities (considering the need to limit urban sprawl through smart growth) and 2) smart green cities (reflecting the preservation and (re-)development of urban green infrastructure). The paper suggests that there is the need to balance these two aspects to develop a systemic approach towards smart-compact-green cities. A hierarchical target system grounded on four characters for smart compact and smart green cities is developed. Smart-compact-green cities can be characterized through a 1) smart environment of compact and green cities, 2) smart multifunctionality of compact and green cities (economic, social, environmental), 3) smart government for compact and green cities and 4) smart governance for compact and green cities. The characters comprise twelve factors defined by 39 indicators for smart compact cities and 44 indicators for smart green cities, respectively. The systemic framework can support researchers and practitioners to develop visions of how existing or future cities can approach smart-compact-green cities in mainstreaming the ecology of and for cities by better understanding the complexity of urban systems and providing a basis for a systematic spatial monitoring.
\end{abstract}

\section{Introduction}

The percentage of human population in urban areas is projected to reach $90 \%$ by the end of the 21 st century (United Nations, 2012), reinforcing new kinds of but also old urban problems like urban sprawl (EEA, 2016; OECD, 2012). Urban sprawl is generally viewed as the spatial process of urbanization characterizing unconstrained urban expansion along with urban population growth. In terms of urban forms, urban sprawl can define continuous exurban growth at the fringe of existing built clusters or along roads (Couch et al., 2007). In terms of land use, urban sprawl is associated with single-family houses, extended transportation infrastructures and huge freestanding commercial and industrial estates. Drivers of urban sprawl are for instance associated with the unsystematic land development, the desire of singlefamily houses in green surroundings and a lifestyle demanding more space per capita and automobile use (EEA, 2016). However, urban sprawl results then in various degrees of cumulative economic, social and ecological impacts (see EEA, 2016 for a summary). Despite its negative impacts, urban sprawl is still a growing trend (EEA, 2016; OECD, 2012).

Therefore, it is widely accepted by policy and science that compact cities need to be fostered. A compact city is a spatial form which is characterized by its physical compactness, high-density development and well-equipped public transport (OECD, 2012). The term 'compact city' is in particular used in Europe and the UK whereby in North America 'smart growth' describes a similar concept with a dense, pedestrian- and transit-friendly urbanization (Smart Growth Network, 2003). Through strict land regulations, revitalization of urban centers and brownfields, increasing the quality of life and providing affordable housing, compact city policies aim to respond "(...) to many urban

\footnotetext{
* Corresponding author.

E-mail addresses: m.artmann@ioer.de (M. Artmann),m.kohler@ioer.de (M. Kohler), g.meinel@ioer.de (G. Meinel), jinggan@tongji.edu.cn (J. Gan), cristian.ioja@geo.unibuc.ro (I.-C. Ioja).
} 
problems, such as land consumption in fringe areas, energy and resource waste, air pollution, accessibility, and social segregation" (Neuman, 2005, 17). However, some side-effects hamper a high quality of life in compact cities (e.g., traffic congestion, air pollution).

One main constraint to compact cities (and of interest in this paper) is the low proportion of urban green spaces (Haaland and van den Bosch, 2015; Neuman, 2005). Urban green spaces (or "urban green") are spaces in an urban environment which have any amount of vegetation, such as parks, urban agriculture, urban forests, residential gardens, street trees or roof gardens (Breuste et al., 2013). The green infrastructure concept stands out as a multi-object strategic planning approach implementing these different kinds of urban green spaces on various scales (Hansen and Pauleit, 2014). Urban green is increasingly acknowledged as the main supplier of ecosystem services supporting human well-being in cities (Breuste et al., 2013). Benefits of green areas ought to be supplied where the demand exists, especially since the effects of green spaces are spatially confined. However, especially in compact cities, the supply of ecosystem services is lower than its demand (Larondelle and Lauf, 2016). There is a deficiency in clear visions on how to approach compact and green cities (Haaland and van den Bosch, 2015; Larondelle and Lauf 2016). In particular, it lacks integrative concepts for research and urban planning practice to approach compact and green cities (Artmann, 2016).

To that end, this study aims to develop a systemic conceptual framework for compact and green cities, referred to here as "smart-compact-green cities". The framework links the concepts of smart growth and green infrastructure and argues they are mutually reinforcing. Due to lacking conceptual understanding on how to approach compact and green cities, research is required to investigate how the green infrastructure concept can be expanded to consider the built environment better such as by using the concept of smart growth (Artmann et al., 2017). To our knowledge, the connection of both concepts has only been superficially considered in past research with an emphasis on the conservation of green infrastructure through smart growth (Benedict and McMahon, 2002; Daniels and Lapping, 2005). Our approach therefore aims to further explore how smart growth and green infrastructure can feed into an integrative target system for compact and green cities.

The smart-compact-green city framework can be considered an indicator-based target system which approaches: 1) smart compact cities considering the need to limit urban sprawl through smart growth, and 2) smart green cities reflecting the preservation and (re-)development of urban green infrastructure. Indicators as defined by Heink and Kowarik (2010) are valuable tools supporting science and planning to understand complex systems (e.g., compact and green cities). So far, a range of indicators are developed and applied to describe in particular spatial patterns of smart growth (e.g., share of single family lots (Barbour and Deaking, 2012), mix of land uses (Cervero, 2006)) and green infrastructure (e.g., accessibility (Grunewald et al., 2017), multifunctionality of urban green spaces (Lovell and Taylor, 2013)). However, to our knowledge no systemic development of sets of indicators interlinking the concepts of green infrastructure and smart growth has been done for spatial monitoring and planning analysis. Moreover, these studies focus on either compact cities or green infrastructure neglecting the interdependence between both dimensions. Thus, the aim of the paper is not to develop new indicators but to interlink existing indicators based on the concepts of green infrastructure and smart growth. This is expected to provide a description of the complex smart-compact-green city system and a basis for an integrated spatial monitoring.

The smart-compact-green city framework can be either used by researchers or planning practice to mainstream visions of how future cities can be developed or to evaluate and monitor the success of already existing cities aiming to approach compact and green cities. Like Giffinger et al. (2007), who developed a hierarchical target system for smart cities in general without focusing in particular on smart growth, compact cities or green infrastructure, we operationalize the theoretical background for smart-compact-green cities by using a hierarchical target system defining at first characters, then factors and finally indicators.

\section{Theoretical conceptualization of smart-compact-green cities}

Smart cities are a popular concept for science and policy to promote urban sustainable development. However, the concept is not well-defined and describes various perspectives (Vanolo, 2016). For instance, smart cities can refer to a smart economy (e.g., communication and information technologies), smart people (e.g., human capital), or smart governance (e.g., e-governance or e-democracy) (Giffinger et al., 2007). Smart cities generally - and also in this study - represent “(...) the final goal of a virtuous path - along which investments are addressed to achieve a sustainable growth, in economic and environmental terms - aimed at improving the quality of life of citizens (...)" (Papa et al., 2013,13). Smart growth can then describe in a wider sense an economic development path balancing growth with a careful use of natural resources and social inclusion of urban residents (EC, 2010). Smart growth can be seen as a bottom-up response to counteract urban challenges impacting living quality such as air pollution or loss of open spaces (Albino et al., 2015). The way in which this final goal can be achieved for smart-compact-green cities will be developed throughout this section.

The focus of research on smart growth is on strategies aiming to manage urban sprawl, increase densities, provide mixed land uses, reduce public development costs and improve urban built-up aesthetics and quality of life in cities (Downs, 2005; Vanolo, 2016). Thereby, smart growth is often used synonymously with compact cities (Whitehead, 2012). This is also how we define smart growth: a process to achieve compact cities as a sub-target of smart cities. The economicoriented European smart growth strategies (EC, 2010, 2012a) stress that especially natural ecosystems and green infrastructure, such as supporting local economies by increasing the attractiveness of areas for tourists through green infrastructure development, can promote smart growth.

Since the smart city (Albino et al., 2015; Vanolo, 2016) as well as the green infrastructure (Hansen and Pauleit, 2014) concepts lack an agreement on theoretical discourse and their holistic operationalization remains elusive, this section develops the theoretical conceptualization of its multi-dimensional characteristics and embedded factors based on literature reviews covering smart cities (with a specific focus on smart growth), compact cities, and urban sprawl on the one hand, and on the other hand green infrastructure. Based on the literature review, four characters of smart-compact-green cities are considered reflecting the need to consider cities as complex socio-ecological systems (McPhearson et al., 2016): 1) smart environment, 2) smart multifunctionality, 3) smart government and 4) smart governance. These characters mirror the reconciling demands to simultaneously promote densification within the grey infrastructure through smart growth (smart compact city) and to secure the protection and (re-)development of the green infrastructure (smart green city). The study suggests that there is the need to balance these two aspects to develop a systemic approach towards smart-compact-green cities (see Fig. 1). Based on the factors of each characteristic, we further specify smart-compact-green cities by developing a set of indicators. The detailed list of indicators can be found in the Appendix A and Appendix B (Appendix A: Indicators for analyzing smart compact cities; Appendix B: Indicators for analyzing smart green cities).

\subsection{Conceptualizing smart environment of compact and green cities}

Smart cities need to consider the environment as essential for securing sustainable growth and limiting urban sprawl (Giffinger et al., 2007). Therefore, the first characteristic in operationalizing smart- 


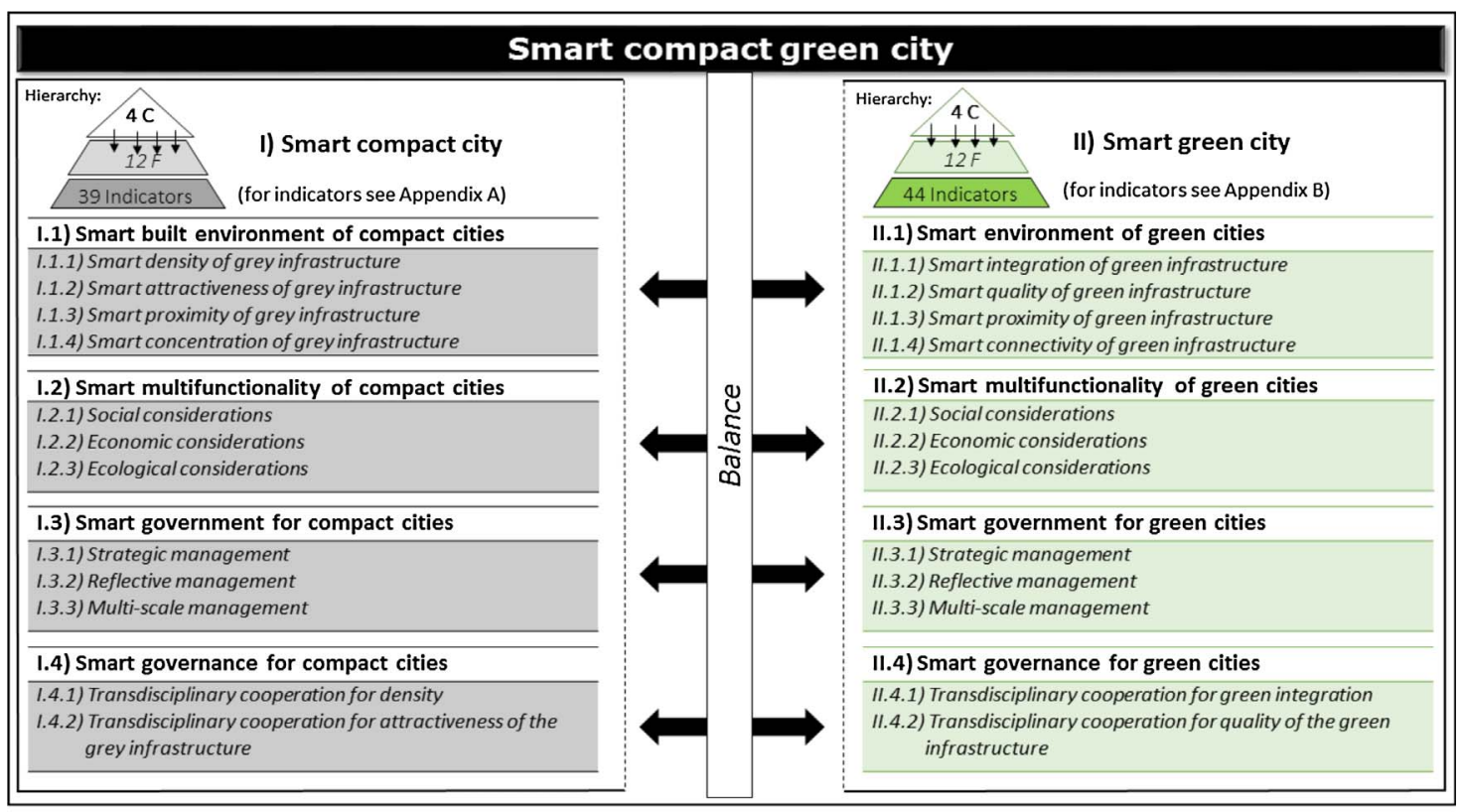

(C) Artmann \& Kohler, IOER 2017

Fig. 1. Characters (C) and factors (F) for the systemic smart-compact-green city framework.

compact-green cities is a smart environment reflecting the built as well as the (semi-)natural environment of the urban ecosystem. For further clarification, four factors were elaborated and were specified through indicators considering a multi-object approach. The multi-object approach reflects the diversity of built-up lands and green spaces and thus provides an integrated picture of the urban ecosystem and its spatial patterns. Such a multi-object approach is demanded for smart growth to promote mixed land uses (Durand et al., 2011) and for green infrastructure planning to more precisely target where to integrate urban green spaces into built-up types (Hansen and Pauleit, 2014).

\subsubsection{Smart density and green infrastructure integration}

Density is the most used criterion to define urban sprawl (Galster et al., 2001; Krehl et al., 2016). Density can be measured through the intensity of activities (e.g., living, working) and its related built-up areas and functional or physical densities (e.g., residential areas per land unit) (Krehl et al., 2016; OECD, 2012). Creating areas of high density often implies promoting space-efficient urban forms and vertically developed building instead of horizontal, low-density developments. In particular, low densities of commercial/industrial and residential areas contribute to urban sprawl (Artmann, 2013). Therefore, a "smart built environment of smart growth" can be approached through land use intensification such as of these built-up types at the site scale (Haaland and van den Bosch, 2015; Smart Growth Network, 2003). However, especially urban morphology types of high densities correlate with the lack of urban green spaces (Artmann, 2013). We suggest applying the principle of "integration" addressed by the green infrastructure concept for the development of a "smart environment of a green city" (see Fig. 2). The green infrastructure concept suggests a functional or physical integration of green spaces into the planning of grey infrastructure (Hansen and Pauleit, 2014). For instance, the integration of green infrastructure can be done through green roofs to decrease surface water runoff in highly sealed commercial areas (Haase and Nuissl, 2007), sky gardens in residential areas to compensate a lack of ground-level greenspaces (Tian et al., 2012), street trees to reduce $\mathrm{CO}_{2}$ emissions (Soares et al., 2011) or implementing small gardens such as those related to schools to support biodiversity as part of the green network (Ioja et al., 2014a, 2014b).

\subsubsection{Smart attractiveness and quality of compact and green cities}

Smart compact cities should secure high-quality, built-up land in regards to the attractiveness of housings and their physical environment (Giffinger et al., 2007; Smart Growth Network, 2003). In particular, revitalization of urban centers should reflect different aspects of the smart city and smart growth literature (e.g., Albino et al., 2005; Downs, 2005; Giffinger et al., 2007; Smart Growth Network, 2003): aesthetics and design of different kinds of grey infrastructure (e.g., commercial areas to secure a high quality of stay), a pedestrian-friendly street design, and safe residential areas.

For smart green cities, a focus should be set on the high quality of the urban green spaces in the built environment (Kambites and Owen 2006). Regarding compact cities, the argument goes that high-quality green infrastructure can compensate for the quantitative lack of green (Haaland and van den Bosch, 2015). The quality is determined by vegetation types and spatial patterns, both influencing the provision of ecosystem services like micro-climatic effects (Lehmann et al., 2014). In order to take into account the necessary multi-scale planning of green infrastructure (Hansen and Pauleit, 2014), the quality of green spaces for compact and green cities should consider urban green spaces at site, city and district as well as regional and national scale (Artmann et al., 2017).

\subsubsection{Smart proximity of compact and green cities}

Proximity is considered as "(...) an important morphological characteristic of a compact city" (OECD, 2012, 81). Proximity describes the distance between different types of land uses and their related activities within a given urban area (e.g., between working, which in our framework refers to commercial/industrial areas and social infrastructure, and living) (OECD 2012). Specifically, proximity can be understood as the distance residents need to get from “(...) any 'home' or residential square to every other 'target' or employment square" (Galster et al., 2001, 697). Therefore, residential areas are not mirrored as a separate indicator. Since, in smart growth literature, proximity is defined by the proximity of transit stops of buses or subways (Durand et al., 2011), the proximity to public transport should be targeted for smart compact cities as well.

Proximity to green spaces, as understood in this study, is the distance between residential areas to different kinds of urban green spaces. 
Low spatial efficiency

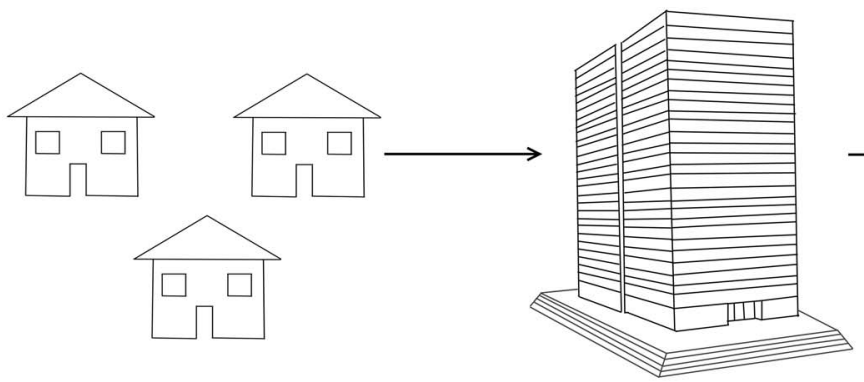

\section{Green infrastructure integration}

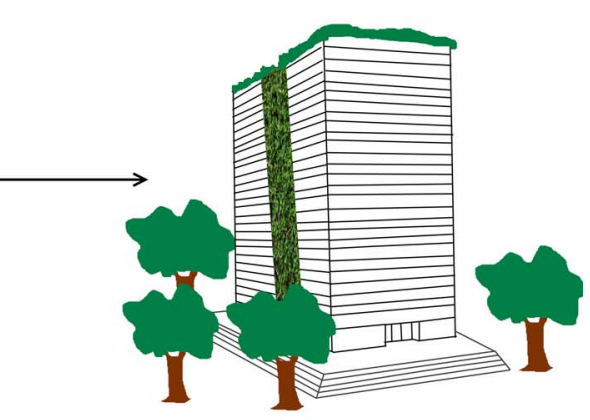

Green integration into

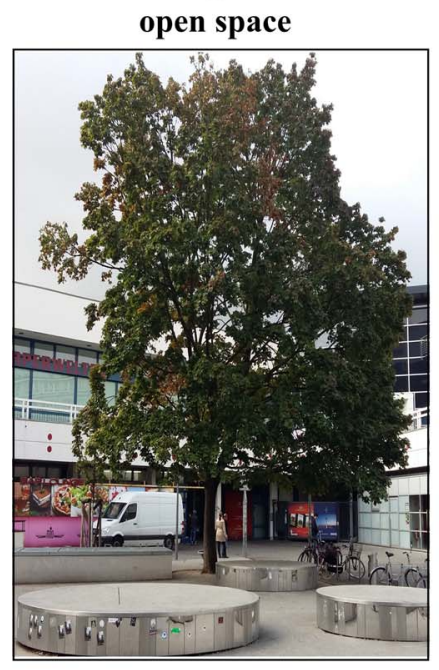

Green integration along transport areas

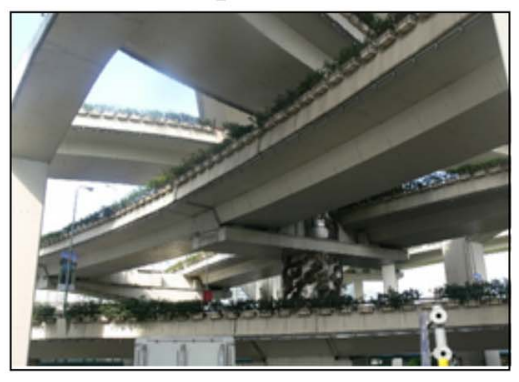

(C) Artmann, IOER 2017
Green integration into commercial building

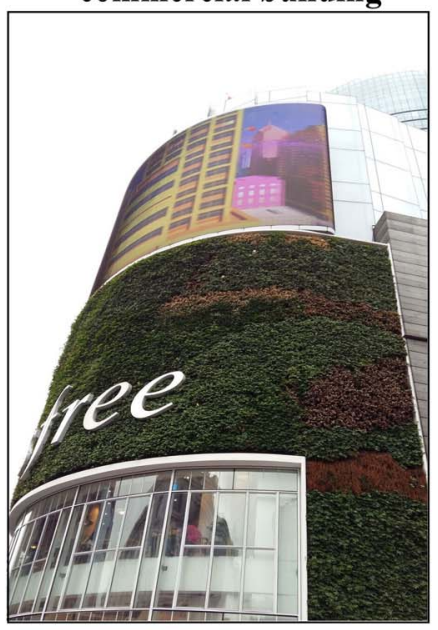

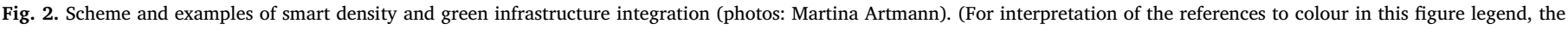
reader is referred to the web version of this article.)

Short distances between urban green areas and dwellings can maximize the urban green ecosystem benefits like supporting recreation (Grunewald et al., 2017). Of crucial importance for the living quality in cities in general and in particular in compact cities is the supply of recreational areas, which should be a reasonable pedestrian distance and be accessible to the public. Urban green spaces with recreational functions and public access are mostly parks, cemeteries, forest and woods, general green areas, waterbodies including flowing and standing bodies of water as part of the green infrastructure and agricultural land such as grassland and orchard meadow. Threshold values for recommended distances between urban green spaces for everyday recreation and the place of residence differ in literature between 300 and $500 \mathrm{~m}$ (ibid.).

\subsubsection{Smart concentration and connectivity of compact and green cities}

Since the measurement of density does not provide information on the distribution of built-up land, there is the need to consider the concentration (seen as the clustering pattern) of urban built-up areas (Thomas et al., 2010). Urban built-up areas of high concentration are developed in fewer places within a city administrative limit instead of being scattered (Galster et al., 2001, Fig. 3). To counteract urban sprawl, smart growth needs then to achieve high concentrations of built-up land, people, services and jobs reflected by the concentration of commercial and industrial, residential and transport areas as the major built-up types in the urban fabric (Artmann, 2013). The main assumption is that the agglomeration of urban entities at some urban centers generate higher proximities and higher utility levels of public services and infrastructures while simultaneously limiting costs and reliance on the private car for commuting (Downs 2005; Smart Growth Network 2003).

For smart green cities, the distribution of green spaces is also of importance. Within this study, the concentration of built-up land should result in an even distribution of green spaces which are connected to each other at different scales (Hansen and Pauleit, 2014) to preserve biodiversity or afford recreational areas close to residents (Kambites and Owen, 2006) (see Fig. 3). The connectivity of different landscape elements can be done physically or functionally, implemented through wildlife networks, green belts, stepping-stone networks of small habitat patches and blue-green corridors (Davies et al., 2015). 
Low concentration

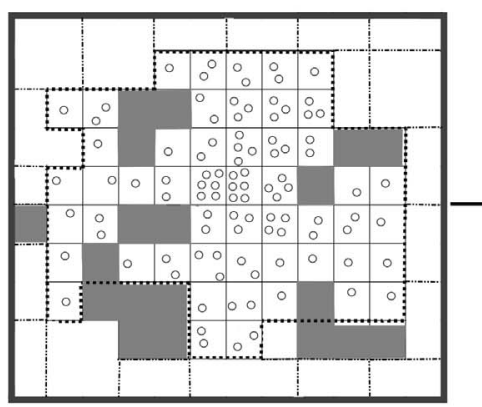

High concentration

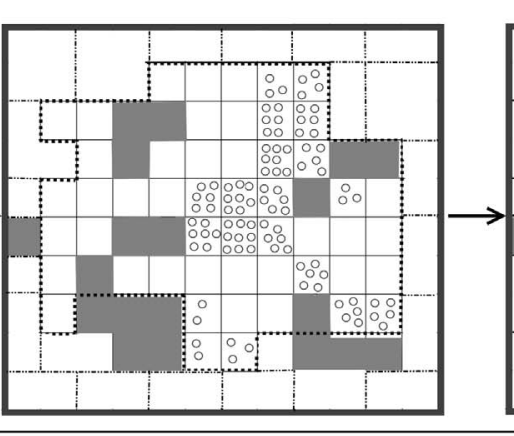

Green infrastructure connectivity

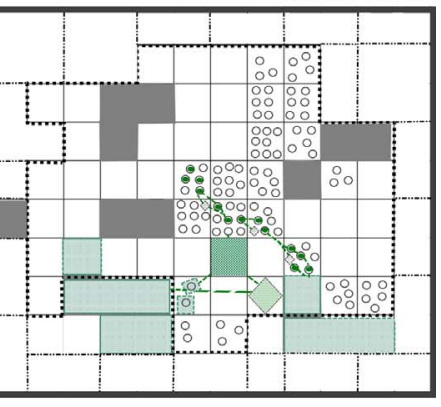

Metropolitan area border

........... Urban area border

One-quarter of a square mile

Square mile

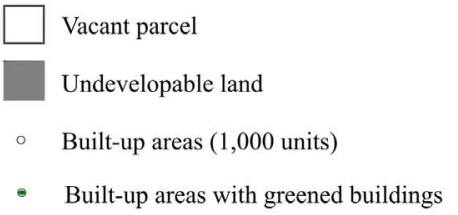

Green interim use

Natural green areas

Public green areas

Private green areas

Green infrastructure corridors

(C) Artmann, IOER 2017

Fig. 3. Scheme of concentration and green infrastructure connectivity (based on the visualization of concentration by Galster et al., 2001).

\subsection{Conceptualizing smart multifunctionality of compact and green cities}

As envisioned by the European Commission (EC, 2012a), innovations evolve when economic, social and environmental benefits are created through sustainable growth strategies. We argue, like the European Commission (EC, 2012a), that facing current challenges such as climate change or biodiversity loss, there must be a development of synergies between the three sustainability dimensions and smart and green cities. Compact development has a wide range of economic, social and environmental benefits limiting the consequences of urban sprawl (EEA, 2016). Smart growth therefore targets a multifunctional mix of uses promoting proximity to working, shopping and recreation (see Section 2.1.3), resulting in multi-dimensional benefits (Smart Growth Network, 2003). A key feature of green infrastructure planning is the holistic and strategic targeting of its ecological, social and economic functions as well (Benedict and McMahon, 2002; Kambites and Owen, 2006). The multifunctional approach of green infrastructure also fits well with compact cities since it targets maximizing synergies of ecosystem services and their related social, ecological and economic benefits where space is limited (Andersson et al., 2014). Therefore, for an integrative picture of potential synergies under the light of a sustainable development this second character, smart multifunctionality, focuses on multifunctionality of compact and green cities and its social, economic and ecological dimensions.

\subsubsection{Smart social consideration for compact and green cities}

According to the European smart and sustainable growth strategy, which puts smart growth in a wider context, smart growth must address social challenges such as job provision (EC, 2010). Jepson and Edwards (2010) found that smart growth strategies indeed comprise targets focusing on job supply. However, smart growth also targets the supply of affordable housing for all income groups and housing diversity that fosters interactions among diverse population (Jepson and Edwards, 2010). By reflecting the interests of all residents through a distinctive and unique, high-quality built environment (see Section 2.1.2), smart growth also aims to create a sense of place and civic pride. High-quality communities supporting the sense of place can be considered as having high economic value as well (Smart Growth Network, 2003). In this regard, green infrastructure can help in place-making and improve the distinctiveness of different areas (EEA, 2011).

The social dimension is also an important aspect of green infrastructure planning considering impacts by urban green spaces on human well-being (Kambites and Owen, 2006). Indeed, densification and greening should consider the promotion of health benefits for urban residents. High levels of mixed land uses and residential density can support physical activities and contribute to public health (Frank et al., 2005). The provision of green spaces at close proximity to urban residents foster physical activities contributing to cardiovascular health (Richardson et al., 2013). However, close proximity to and better supply of urban green spaces might increase property values and displace less wealthy residents (Haaland and van den Bosch, 2015). Therefore, urban planners ought to monitor the distribution of environmental quality and its access among the population in terms of environmental justice. Environmental justice is defined as equal access to a healthy environment to all strata or classes of population (Schwarte and Adebowale, 2007). The planning for smart-compact-green cities should therefore consider impacts of densification on different population groups (Artmann et al., 2017) to ensure, for instance, that vulnerable residents such as elderly and children have good access to urban green spaces (Grunewald et al., 2017). Urban green also supports social cohesion. A case study in the Netherlands showed that urban parks provide a means for ethnic groups to mix with each other, stimulating social cohesion (Peters et al., 2010). Also highly dense builtup areas can moderately foster social interactions and support greater use of local services (Bramley et al., 2009).

\subsubsection{Smart economic consideration for compact and green cities}

Since economic growth is a central objective of national policies, it 
is worth emphasizing to urban planners and local policy makers the economic benefits of compact cities. Thus, a shift from the simple target to protect the environment from urban sprawl towards an economic green growth perspective can convince urban actors to introduce compact city strategies (OECD, 2012). Indeed, there are economic benefits for urban authorities through compact development. For instance, an increase in population density in medium-sized urban areas decreases the municipal spending on public services per capita as demonstrated in Latin America (De Duren and Compeán, 2015). To increase job supply, green cities profit from a positive image and therefore attract more firms than highly sealed cities (Jang and Kang, 2015). The degradation of the urban ecosystem such as the loss of urban green spaces due to densification is related to a loss of ecosystem services often involving economic costs (MEA, 2005). Therefore, economic benefits provided by green infrastructure should be considered by cities when it comes to decreasing green space during densification processes.

It is argued that urban planning is constrained by decreasing financial resources despite rising complexity approaching urban sustainability (Dalal-Clayton and Bass, 2002) and economic and financial activities are a major driver of urban sprawl (EC, 2012b). Therefore, economic-fiscal instruments aiming to limit urban sprawl and to promote green cities should be taken into account by urban planning. For instance, in some European countries (e.g., Poland, Slovakia) developers are required to pay a fee for the soil sealed, the amount of which depends on the value of the soil lost through urban sprawl (EC, 2012b). To overcome limited financial resources for urban green infrastructure, planning systems should include financial instruments in green development approvals (Kambites and Owen, 2006).

\subsubsection{Smart ecological consideration for compact and green cities}

One main value of the concept of smart growth is its economicgrowth-oriented urban development while protecting land and the environment. In this regard, the main pillars are the preservation of natural areas at the urban fringes of urban sprawl (related in the framework to the smart compact city) and green spaces within the built-up areas (related in the framework to the smart green city) (Daniels and Lapping, 2005). Both pillars provide manifold stepping stones towards sustainable ecological development (ibid.).

To frame the indicators for smart-compact-green cities within this factor, the categorization of ecosystem services into four groups (regulation, supporting, supplying, cultural ecosystem services (MEA, 2005)) can be applied since both dimensions of the compact and green city likewise affect all ecosystem services categories. Indeed, ecosystem services can support urban planning in reflecting the complex ecological impacts due to densification when planning compact and green cities (Artmann et al., 2017). For instance, the limitation of urban sprawl through green belts at urban fringes can contribute to climate change mitigation (Gill et al., 2007). Integrating green infrastructure into the grey infrastructure (see Section 2.1) through the installation of green roofs supports stormwater management and provides space for recreation in densely built-up areas (Oberndorfer et al., 2007). Supporting and supplying ecosystem services are addressed along the boundaries of urban sprawl by hindering fragmentation of habitats and loss of agricultural areas for food provisioning (Artmann, 2013). Through greening roads and local garden initiatives biodiversity can also be supported in dense urban areas (Tratalos et al., 2007). When implementing edible green walls or fruit trees in public urban parks the provision of food can be promoted within urban built-up areas (Russo et al., 2017).

\subsection{Conceptualizing smart government for compact and green cities}

Smart growth requires powerful institutional leadership as well as coordination. Smart government includes government-only action and can help to remove legal barriers preventing densification and to define and prioritize one or more strategic planning objectives/actions (Albino et al., 2015; EC, 2012a). The same can be true for green infrastructure planning, where strategic actions such as integration of green and grey infrastructure can be prioritized (Davies et al., 2015). Therefore, this third character illustrates smart government as a main pillar to strategically implement and monitor smart-compact-green cities which is reflected by its integration into the other characters developed.

\subsubsection{Strategic management}

The ability of planning to embrace appropriate priorities and specific actions for planning of green infrastructure considering its multifunctionality and its important components such as ecosystem service supply (see Section 2.2.3), stakeholder preferences (see Section 2.4) and multi-objects and networks (see Section 2.1) is comprised in the term strategic management (Hansen and Pauleit, 2014). In particular, planning strategies for compact and green cities need a comprehensive planning (Kambites and Owen, 2006) to reflect the spatial heterogeneity and socio-ecological complexity of urban ecosystems and landscapes (Artmann et al., 2017) which is also mirrored by the framework developed in this study.

To adapt to (changing) local conditions (e.g., shrinking or growing cities), relevant scales of action (see Section 2.3.3) and actors involved, urban planners ought to apply a set of strategies as part of strategic management for compact and green cities. These strategies can include the revitalization of urban brownfields in shrinking cities to reduce land take, in particular at the urban fringes (Artmann, 2013). Brownfields can also be greened for interim uses like recreation (Rall and Haase, 2011). Also, the strengthening of the city center can be a task to improve the quality of the built environment. This is supported by current trends of re-urbanization such as in former shrinking cities in the UK or Germany where vacant housing has decreased especially in more attractive districts (Rink et al., 2012). The greening of vacant lots can make valuable contributions since they may limit certain crimes and provide some health benefits (Branas et al., 2011).

A common challenge among compact and green cities is the uncertainty in ensuring/enhancing green space quality while meeting densification and multifunctionality objectives (Haaland and van den Bosch, 2015). In this regard, smart government for compact and green cities needs strategies on how to deal with conflicts between targets such as densification, living quality, and ecosystem services in a context of rising concerns about environmental states and urban sprawl processes (Torre et al., 2014). Conflicts for green infrastructure planning can also arise for instance between uses of green spaces for nature conservation versus recreational uses (Artmann et al., 2017). In addition, institutional barriers (e.g., lacking capacity for implementing green infrastructure (Davies et al., 2015) should be considered by a smart government.

To approach conflicts and uncertainties during the implementation of compact and green cities, a close, cross-sectoral cooperation in the city administration is important. Particularly within the complex urban ecosystem, cross-scale and cross-departmental co-operations are needed to develop systemic urban management plans for compact and green cities (Artmann et al., 2017).

\subsubsection{Reflective management}

Integrative planning for compact and green cities needs to analyze the state of landscape and nature and potential impacts of developed planning measures and objectives (Artmann et al., 2017). Thus, the second factor sees the need of a reflective management that is information-driven and aware of intended, current and past urban developments of the environment (see Section 2.1) and their multifunctional impacts (see Section 2.2). In light of the smart city concept and its focus on informational and technological aspects, the need for monitoring is obvious. Thus, “(...) the Smart Cities initiative seeks to improve urban performance by using data, information and Information Technologies (IT) to provide more efficient services to citizens, to monitor and optimize existing infrastructure (...)." (Marsal-Llacuna 
et al., 2015, 621) Such monitoring supports smart growth initiatives by proactively analyzing impacts of various development patterns to secure a high living quality during densification (Smart Growth Network, 2003) or providing information about infill development potential (e.g. brownfield registers) (Artmann, 2016). Through monitoring current planning processes of green infrastructure, countermeasures can be set when strategies do not achieve desired impacts. To ensure a straightforward approach towards compact green cities, the monitoring system should be interlinked with targets. To foster compact cities, urban planning and decision makers can set explicit targets of daily land take to limit urban sprawl (EC, 2012b) or expand the amount of space for green areas (Grunewald et al., 2017).

\subsubsection{Multi-scale management}

The success of urban growth management depends on the cooperation between various scales (Siedentop and Fina, 2012). Since a comprehensive, green infrastructure network is ideally developed within the city at different scales and crosses over into peri-urban and rural sites, local to cross-boundary cooperation for its implementation is required (Davies et al., 2015; EC,2013) (see Section 2.1).

Smart multi-scale management should consider multi-scale cooperation and benefits arising through green and compact cites. Multiscale impacts through urban sprawl arise, for instance, due to an increase in dependence on cars and therefore to an increased demand for energy and multi-scale impacts through associated emissions by traffic (De Ridder et al., 2008). Therefore, planning should not only consider the welfare of residents arising through smart growth but interests of their entire region by shifting power for land-use planning from the local to regional level (Downs, 2005). In regards to green cities, individual trees can contribute to cooling the urban air and surface temperatures at site scale, but their ecosystem services can be maximized when embedded in a larger green network (Andersson et al., 2015). To ensure an extensive approach towards compact green cities, urban planning should take up multi-scale targets and requirements set from European to local scale as reflected by the EU Water Framework Directive (Artmann et al., 2017).

\subsection{Conceptualizing smart governance for compact and green cities}

The planning of green infrastructure, as well as smart growth, strategies call for a transdisciplinary approach sharing knowledge between academics and non-academics, while also motivating a broad range of local stakeholders such as residents, economic representatives, and non-governmental actors (Kambites and Owen, 2006; Scott 2007). We argue that these non-governmental actors comprise the fourth character of the smart-compact-green city framework and can contribute directly or indirectly to smart growth and green cities in terms of urban environment qualities and densification. A smart governance is hence understood as groups of urban stakeholders in addition to city administrations defined as smart government (see Section 2.3) ensuring the structural setup required to realize compact and green cities.

\subsubsection{Governance for smart density and green integration}

The residential preferences of the individuals or households for single-detached family housing and low-density areas at urban fringes that provide access to natural amenities are often raised as a main driver of urban sprawl (Howley, 2009; Williams et al., 2010). Thus, residents influence the intensity of urban sprawl. Moreover, residents can take actions in greening building. In Munich, Germany, residents and investors alike are engaged in a competition to green courtyards and roofs in residential and commercial areas (Artmann, 2013). Investors as economic representatives are also crucial to limiting urban sprawl since it is argued that urban sprawl can be considered the consequence of liberal markets giving the freedom to individuals to dispose of the supply and demand of land (Bruegmann, 2005). As a tertiary stakeholder in urban planning, non-government organizations
(NGO) can push sustainable urban development forward and for instance raise awareness (Smart Growth Network, 2003) such as on the impacts of urban sprawl or possibilities for greening buildings. Another important group of actors related to compact green cities are researchers. They can be consulted during the planning decision-making process, for example, to develop indicators to quantify the accessibility of urban green spaces (Grunewald et al., 2017).

\subsubsection{Governance for smart attractiveness and green quality}

Besides supporting dense urban development and green integration economic representatives, the public, NGOs and researchers can contribute to provide better qualities, and hence attractiveness, of the grey infrastructure. For instance, residents can be directly involved in the improvement of the attractiveness of buildings and their neighborhoods. A high-quality built environment then also attracts investors who are major players in implementing smart growth (Smart Growth Network, 2003). In regards to improving the quality of green infrastructure, public urban greening or garden communities are examples, providing access to local food, implementing new environmentallyfriendly agricultural practices, and securing ordinary ecological diversity (Tidball and Krasny, 2007). NGOs and researchers can support communities to develop community interaction for improving and maintaining the quality of neighborhoods and to develop a sense of community (Smart Growth Network, 2003).

\section{Discussion}

\subsection{Applying the smart-compact-green city framework}

To approach compact and green cities, the application of the systemic smart-compact-green city framework provides indicators 1) for land-use monitoring and 2) for assessing and supporting urban development strategies to make imbalances between smart compact and smart green cities visible.

a The structure of land uses and related land cover determines the functioning of cities. Only if mixed land uses, density and quality including green supply are implemented can a city of short distances be achieved. Therefore, high-resolution spatial information is necessary and in particular a monitoring of its small-scale changes (Meinel, 2014). To describe such structures, states, and changes, the smart environment and multifunctionality indicators are useful (see Sections 2.1, 2.2). Some indicators suggested in our framework have already been implemented as a part of the German Monitor of Settlement and Open Space Development (IOER monitor) since 2010 (Krüger et al., 2013). However, examples of possible indicators for a smart environment of compact and green cities, their related criteria and monitoring presented in Table 1 show that a mix of additional methods and in particular small-scale data sources are needed to comprehensively capture all factors. Thus, besides GIS analysis making the density of the grey infrastructure visible, mapping green roofs at a small scale, surveying residents to assess access to different patterns of built-up sites or new technologies should be applied through the smart-compact-green city framework. To our knowledge there is currently no spatial monitoring providing such an integrated picture of compact and green cities and their changes over time. Our conceptual paper can be considered as a first step to provide a framework for such an integrated spatial monitoring.

b The analysis of urban planning policies and strategies can contribute to an understanding of policy paradigms within a given period (Hansen et al., 2015). Since there is a strong need to shift from the compact city dogma to an integrative view on compact and green cities (see Section 1), the analysis of urban planning documents can proof how far this paradigm shift has reached the planning practice. To systematically analyze planning strategies, we suggest conducting a content analysis using a coding procedure such as was 


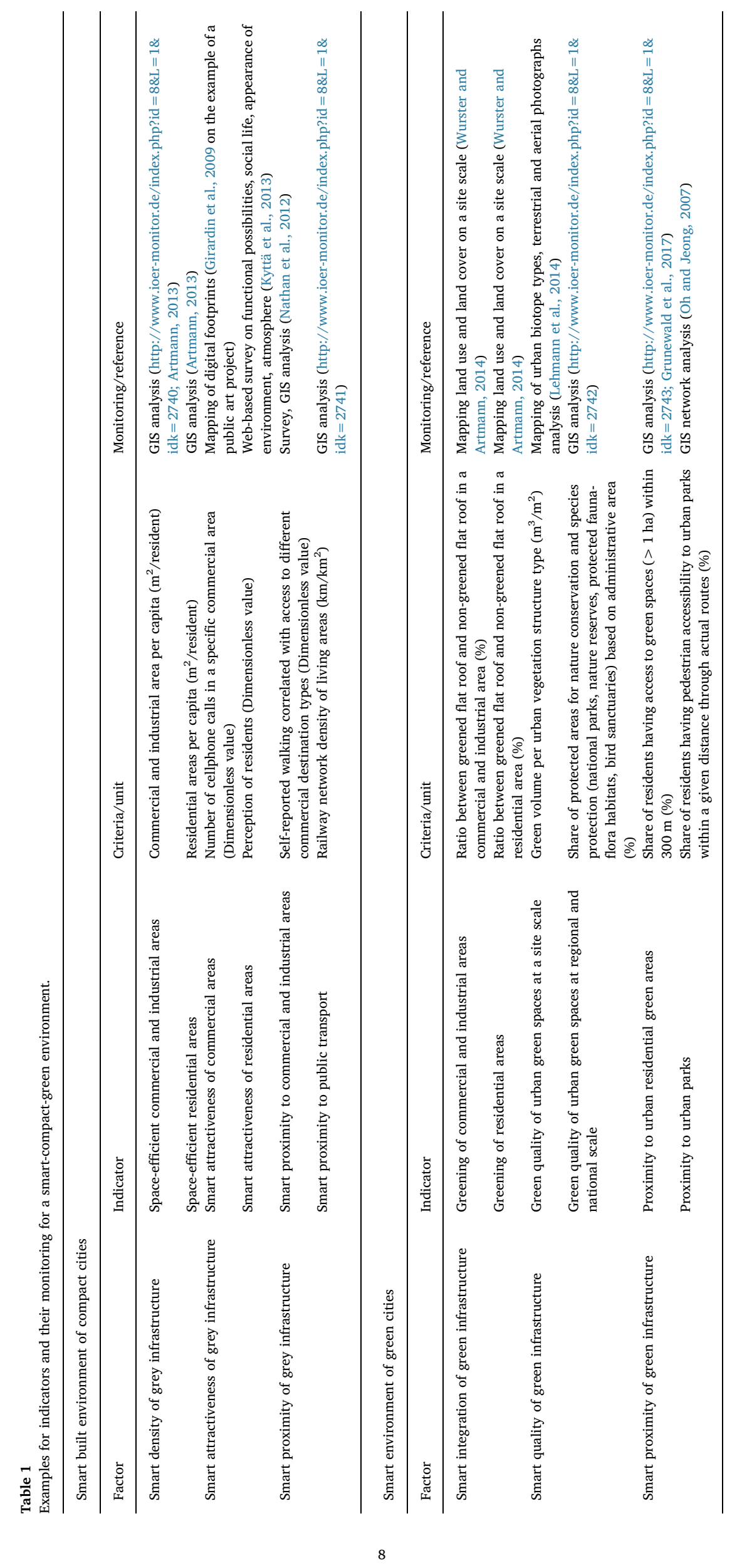


done by Wald and Hostetler (2010) in assessing the performance of Florida's Land Development Regulations in conserving open spaces. The indicators suggested in this paper can be developed further and function as coding criteria by formulating them as questions (e.g., "Are space-efficient commercial and industrial areas demanded by planning?" 1 = yes, $0=$ no; see indicator I.1.1.1, Appendix A). The cities can then score one point if they address the issue in their policy.

The land-use monitoring and planning analysis can help research and planning to better visualize any imbalance between approaching compact and green cities. By summing up the scores gained through planning analysis or land-use monitoring (per factor, character and aspect), it becomes visible to what extent a balance between targets related to smart compact cities and smart green cities has been achieved (see Fig. 1, Section 1). Before that, a normalization of the data and its different units (see Table 1 ) is necessary as suggested by Larondelle and Lauf (2016) when evaluating multiple urban ecosystem services. Besides, since the importance of the different characters and factors might differ between cities and their local framework conditions (e.g., between growing or shrinking cities) as well as their different departments (e.g., between nature protection and transport planning), a subjective rating of the indicators, factors and characteristics by different urban actors can help to consider such varying perspectives (Fischer et al., 2010). In this regard, the future application of the framework in cities with different framework conditions might be interesting to develop comprehensive planning recommendations how to approach compact and green cities.

\subsection{Factors affecting the framework application}

During the development of the smart-compact-green city framework, it became evident that the proposed characteristics and factors can be well grounded theoretically by using the concepts of smart growth for compact cities and green infrastructure for green cities providing an integrated view on compact and green cities, their spatial components and actors across scales. However, we identified three main areas affecting the potential framework application: research limits, the role of smart technology and land-use conflicts.

First, despite the theoretical grounding of the developed factors and indicators, their application in practice can be constrained by a lack of conceptual understanding. For instance, more research is needed to understand the production of multiple ecosystem services (see factors I.2.3 and II.2.3) in cities in particular in relation to their built infrastructure and across scales (McPhearson et al., 2016). In general, to understand interconnections between urban sprawl and its social, ecological and economic effects (see Section 2.2) more detailed studies are needed (EEA, 2016). The application of our framework might also be limited by lacking data, which would for instance constrain investigations on densities values, especially in cases where a small scale is used, such as for built-up areas (Krehl et al., 2016) (see Section 2.1.1).

Second, the use of technology is a key component of the smart city concept (Albino et al., 2015) and should be reflected further when refining and applying our framework. For instance, it is argued that smart government makes use of Information and Communications Technology (ICT) to strategically manage growth and innovation by interconnecting with other planning departments, residents and businesses. ICTs offer the government the possibility to be more transparent, accountable, using resources more effectively and empowering and educating citizens through interactive platforms and crowdsourcing techniques so that they are capable of engaging in a debate about their own environment (Albino et al., 2015; Allwinkle and Cruickshank, 2011). Thus, ICTs can contribute to smart environment (see Table 1), government and governance for smart-compact-green cities. However, despite the positive role of smart technologies, one must ask to which extent technology can support smart urbanism. Relevant risks can refer to unequal access to ICTs (Luque-Ayala and Marvin, 2015), costs and data security such as related with cloud computing (Hashem et al., 2014). Suitable technologies ought to be based on local circumstances and integrated into strategies and mechanisms to promote smart-compact-green cities.

Third, in compact and green cities, limited land resources (Torre et al., 2014), competition between land-uses and ecosystems services (Kovács et al., 2014; Tudor et al., 2015), as well as high cultural diversity and elevated risk to break the law (Ioja et al., 2014b) are ideal conditions for incompatible interactions between actors (Hersperger et al., 2015). Land-use conflicts in compact and green cities are characterized by more complexity and have diverse participant pools (also diverse in dynamic and socio-cultural norms) claiming to represent the public interest (Torre et al., 2014). Therefore, we took the conflicts (such as related to land use) into consideration by strategically managing compact and green cities with separate indicators (I.3.1.3 and II.3.1.3). Future research is needed to assess the added value of our integrative framework in supporting urban planning to deal with landuse conflicts arising in compact and green cities and their different characters and factors.

\section{Conclusions}

Researchers and urban planners are confronted with the central challenge of how to approach compact and green cities at the same time. This paper contributes to a better understanding on how compact and green cities can be advanced. By linking the concepts smart growth (as a goal of smart cities) and green infrastructure, a hierarchical indicator-based target system was developed which is grounded on four characteristics: 1) smart environment, 2) smart multifunctionality; 3) smart government and 4) smart governance for compact and green cities.

This framework provides a systemic approach for compact and green cities by considering the complexity of cities as socio-ecological systems. In general, such an integrated science is crucial for future research in urban ecology to understand the complexity of urban systems (McPhearson et al., 2016). Due to the systemic composition of our framework, its application will need the integration of various sources and types of data such as spatial (e.g., sealing degree, density), quantitative (e.g., economic benefits of compact cities) and qualitative data (e.g., preferences of green spaces by different population groups). Since time and financial resources are often strained in planning, new assessment and monitoring requirements need to be balanced with everyday realities. Therefore, a next step to this study is to develop practical criteria and to consider current data situations. Therefore, in the application of the framework, it might be that not all indicators can be fed with data. Future research should identify potential data sources and crucial data gaps that need to be filled for understanding the progress, opportunities and needs of actions to approach smart-compactgreen cities.

\section{Funding}

The Romanian research was supported by a grant from the Romanian National Authority for Scientific Research and Innovation (PN-III-P4-ID-PCE-2016-0635). The other researchers did not receive any specific grant from funding agencies in the public, commercial, or not-for-profit sectors.

\section{Acknowledgements}

We would like to thank Artem Korzhenevych for his valuable comments on an earlier version of this manuscript. We also want to thank two anonymous reviewers and the guest editors for their constructive comments. 


\section{Appendix A}

See Table A1.

Table A1

Indicators for analyzing smart compact cities.

I) Smart compact city

I.1) Smart built environment of compact cities

I.1.1) Smart density of grey infrastructure

I.1.1.1) Space-efficient commercial and industrial areas

I.1.1.2) Space-efficient residential areas

I.1.2) Smart attractiveness of grey infrastructure

I.1.2.1) Smart attractiveness of commercial and industrial areas

I.1.2.2) Smart attractiveness of residential areas

I.1.2.3) Smart attractiveness of transport areas

I.1.3) Smart proximity of grey infrastructure

I.1.3.1) Smart proximity to commercial and industrial areas

I.1.3.2) Smart proximity to public transport

I.1.3.3) Smart proximity to social infrastructure

I.1.4) Smart concentration of grey infrastructure

I.1.4.1) Smart concentration of commercial and industrial areas

I.1.4.2) Smart concentration of residential areas

I.1.4.3) Smart concentration of transport areas

I.1.4.4) Smart concentration of social infrastructure

I.2) Smart multifunctionality of compact cities

I.2.1) Social consideration for compact cities

I.2.1.1) Consideration of diverse population groups as part of densification

I.2.1.2) Consideration of affordable housing and job supply

I.2.1.3) Interlinking densification with benefits for human health and well-being

I.2.1.4) Increase place-making through quality of urban core areas

I.2.1.5) Targeting social integration along densification

I.2.2) Economic consideration for compact cities

I.2.2.1) Reflection of economic benefits arising through smart growth

I.2.2.2) Consideration of appropriate financial/fiscal support for smart growth

I.2.3) Ecological consideration for compact cities

I.2.3.1) Reduction of urban sprawl to promote regulating ecosystem services

I.2.3.2) Reduction of urban sprawl to promote supporting ecosystem services

I.2.3.3) Reduction of urban sprawl to promote supplying ecosystem services

I.2.3.4) Reduction of urban sprawl to promote cultural ecosystem services

I.3) Smart government for compact cities

I.3.1) Strategic management for compact cities

I.3.1.1) Implementation of set of strategies promoting smart compact cities:

- Strengthening of the primary or secondary city poles

- Mixed uses

- Revitalization contributing to densification

- Conversion/re-use of brownfields

- Development of vacant lots between buildings

- Reduction of vacancy rates

- Increase in moderately high-rise buildings

- Interim uses

- Local suppliers and amenities close to the consumers

- Development close to public transportation nodes (bus, rail, etc.)

- Etc.

I.3.1.2) Reflection of uncertainties for compact cities

I.3.1.3) Consideration of institutional barriers and conflicts (between land uses, ecosystem services) preventing compact cities

I.3.1.4) Consideration of sectoral cooperation within administrative departments to foster compact cities

I.3.2) Reflective management for compact cities

I.3.2.1) Monitoring of compact city strategies and infill development potential

I.3.2.2) Setting targets for compact cities (explicitly mentioned/quantitative objective)

I.3.3) Multi-scale management for compact cities

I.3.3.1) Reflection of multi-scale benefits arising through compact cities

I.3.3.2) Reflection of multi-scale targets and requirements to foster compact cities

I.4) Smart governance for compact cities

I.4.1) Transdisciplinary cooperation for smart density

I.4.1.1) Transdisciplinary cooperation with the public for smart density

I.4.1.2) Transdisciplinary cooperation with NGOs for smart density

I.4.1.3) Transdisciplinary cooperation with researchers for smart density

I.4.1.4) Transdisciplinary cooperation with economic representatives for smart density

I.4.2) Transdisciplinary cooperation for smart attractiveness of the grey infrastructure

I.4.2.1) Transdisciplinary cooperation with the public for smart grey infrastructure

I.4.2.2) Transdisciplinary cooperation with NGOs for smart grey infrastructure

I.4.2.3) Transdisciplinary cooperation with researchers for smart grey infrastructure

I.4.2.4) Transdisciplinary cooperation with economic representatives for smart grey infrastructure 


\section{Appendix B}

See Table B1.

Table B1

Indicators for analyzing smart green cities.

II) Smart green city

II.1) Smart environment of green cities

II.1.1) Smart integration of green infrastructure

II.1.1.1) Greening of commercial and industrial areas

II.1.1.2) Greening of residential areas

II.1.1.3) Greening of transport infrastructure

II.1.1.4) Greening of social infrastructure

II.1.2) Smart quality of green infrastructure

II.1.2.1) Green quality of urban green spaces at a site scale

II.1.2.2) Green quality of urban green spaces at a city and district scale

II.1.2.3) Green quality of urban green spaces at regional and national scale

II.1.3) Smart proximity of green infrastructure

II.1.3.1) Proximity to general green areas

II.1.3.2) Proximity to urban parks

II.1.3.3) Proximity to cemeteries

II.1.3.4) Proximity to forests and woods

II.1.3.5) Proximity to waterbodies

II.1.3.6) Proximity to agricultural land (grassland, orchard meadow)

II.1.4) Smart connectivity of green infrastructure

II.1.4.1) Connectivity through wildlife corridors/habitat networks

II.1.4.2) Connectivity through green corridors/nets/belts

II.1.4.3) Connectivity through stepping stones

II.1.4.4) Connectivity through blue-green network

II.2) Smart multifunctionality of green cities

II.2.1) Social consideration for green cities

II.2.1.1) Interlinking greening of built-up areas with benefits for human health and well-being

II.2.1.2) Consideration of environmental justice as part of green infrastructure planning

II.2.1.3) Consideration of various population groups as part of green infrastructure planning

II.2.1.4) Targeting of social cohesion and interaction as benefit of green infrastructure

II.2.1.5) Increasing place making through green infrastructure

II.2.2) Economic consideration for green cities

II.2.2.1) Reflection of economic benefits arising through green infrastructure

II.2.2.2) Consideration of appropriate funding models for green infrastructure initiatives

II.2.3) Ecological consideration for green cities

II.2.3.1) Greening cities to promote regulating ecosystem services

II.2.3.2) Greening cities to promote supporting ecosystem services

II.2.3.3) Greening cities to promote supplying ecosystem services

II.2.3.4) Greening cities to promote cultural ecosystem services

II.3) Smart government for green cities

II.3.1) Strategic management for green cities

II.3.1.1) Implementation of set of processes and principles for green infrastructure planning:

- Green interim uses

- Site-specific densification

- Green area restoration and re-naturalization

- Greening of brownfields/vacant lots

- Informal planning strategies (e.g., climate protection, allotment, development, unsealing)

- Etc.

II.3.1.2) Reflection of uncertainties for green cities

II.3.1.3) Consideration of institutional barriers and conflicts preventing green cities

II.3.1.4) Consideration of sectoral cooperation within administrative departments for green cities

II.3.2) Reflective management for green cities

II.3.2.1) Monitoring of green infrastructure

II.3.2.2) Setting targets for green infrastructure planning

II.3.3) Multi-scale management for green cities

II.3.3.1) Reflection of multi-scale benefits arising through green cities

II.3.3.2) Reflection of multi-scale targets and requirements to foster green cities

II.4) Smart governance for green cities

II.4.1) Transdisciplinary cooperation for smart green integration

II.4.1.1) Transdisciplinary cooperation with the public for green integration

II.4.1.2) Transdisciplinary cooperation with NGOs for green integration

II.4.1.3) Transdisciplinary cooperation with researchers for green integration

II.4.1.4) Transdisciplinary cooperation with economic representatives for green integration

II.4.2) Transdisciplinary cooperation for smart quality of green infrastructure

II.4.2.1) Transdisciplinary cooperation with the public for smart green infrastructure

II.4.2.2) Transdisciplinary cooperation with NGOs for smart green infrastructure

II.4.2.3) Transdisciplinary cooperation with researchers for smart green infrastructure

II.4.2.4) Transdisciplinary cooperation with economic representatives for smart green infrastructure 


\section{References}

Albino, V., Berardi, U., Dangelico, R.M., 2015. Smart cities: definitions, dimensions, performance, and initiatives. J. Urban Technol. 22 (1), 3-21.

Allwinkle, S., Cruickshank, P., 2011. Creating smarter cities: an overview. J. Urban Technol. 18 (2), 1-16.

Andersson, E., Barthel, S., Borgström, S., Colding, J., Elmqvist, T., Folke, C., Gren, A., 2014. Reconnecting cities to the biosphere: stewardship of green infrastructure and urban ecosystem services. AMBIO 43, 445-453.

Andersson, E., McPhearson, T., Kremer, P., Gomez-Baggethun, E., Haase, D., Tuvendal, M., Wurster, D., 2015. Scale and context dependence of ecosystem service providing units. Ecosyst. Serv. 12, 157-164.

Artmann, M., Bastian, O., Grunewald, K., 2017. Using the concepts of green infrastructure and ecosystem services to specify Leitbilder for compact and green cities - the example of the landscape plan Dresden (Germany). Sustainability 9 (2), 198.

Artmann, M., 2013. Spatial dimensions of soil sealing management in growing and shrinking cities - a systemic multi-scale analysis in Germany. Erdkunde 67 (3), 249-264.

Artmann, M., 2016. Urban gray vs. urban green vs. soil protection - development of a systemic solution to soil sealing management on the example of Germany. Environ. Impact Assess. Rev. 59, 27-42.

Barbour, E., Deaking, E.A., 2012. Smart growth planning for climate protection. evaluating california's senate bill 375. J. Am. Plann. Assoc. 78 (1), 70-86.

Benedict, M.A., McMahon, E.T., 2002. Green infrastructure: smart conservation for the 21 st century. Renew. Res. J. 20 (3), 12-17.

Bramley, G., Dempsey, N., Power, S., Brown, C., Watkins, D., 2009. Social sustainability and urban form: evidence from five British cities. Environ. Plan. A 41, 2125-2142.

Branas, C.C., Cheney, R.A., MacDonald, J.M., Tam, V.W., Jackson, T.D., Ten Have, T.R., 2011. A difference-in-Differences analysis of health, safety, and greening vacant urban space. Am. J. Epidemiol. 174 (11), 1296-1306.

Breuste, J., Haase, D., Elmqvist, T., 2013. Urban landscapes and ecosystem services. In: Wratten, S., Sandhu, H., Cullen, R., Costanza, R. (Eds.), Ecosystem Services in Agricultural and Urban Landscapes. Wiley \& Blackwell, Oxford, pp. 83-104.

Bruegmann, R., 2005. Sprawl. A Compact History. The University of Chicago Press, Chicago.

Cervero, R., 2006. Alternative approaches to modeling the travel-Demand impacts of smart growth. J. Am. Plann. Assoc. 72 (3), 285-295.

Couch, C., Leontidou, L., Arnstberg, K.-O., 2007. Introduction: definitions, theories and methods of comparative analysis. In: Couch, C., Leontidou, L., Petschel-Held, G. (Eds.), Urban Sprawl in Europe. Landscapes, Land-Use Change \& Policy. Blackwell Publishing Ltd, Blackwell, Oxford, pp. 3-38.

Dalal-Clayton, B., Bass, S., 2002. Sustainable Development Strategies: A Resource Book. Earthscan Publications, Oxon.

Daniels, T., Lapping, M., 2005. Land preservation: an essential ingredient in smart growth. J. Plan. Lit. 19 (3), 316-329.

C. Davies, R. Hansen, E. Rall, S. Pauleit, R. Lafortezza, Y. De Bellis, A. Santos, I. Tosics, Green infrastructure planning and implementation The status of European green space planning and implementation based on an analysis of selected European cityregions, 2015, http://greensurge.eu/working-packages/wp5/files/Green Infrastructure_Planning_and_Implementation.pdf (Accessed 24 March 2016).

De Duren, N.L., Compeán, R.G., 2015. Growing resources for growing cities: density and the cost of municipal public services in Latin America. Urban Stud. 1-26.

De Ridder, K., Lefebre, F., Adriaensen, S., Arnold, U., Beckroege, W., Bronner, C., Damsgaard, O., Dostal, I., Dufek, J., Hirsch, J., IntPanis, L., Kotek, Z., Ramadier, T., Thierry, A., Vermoote, S., Wania, A., Weber, C., 2008. Simulating the impact of urban sprawl on air quality and population exposure in the German Ruhr area. Part II: Development and evaluation of an urban growth scenario. Atmos. Environ. 42 7070-7077.

Downs, A., 2005. Smart growth. Why we discuss it more than we do it? J. Am. Plan. Assoc. 71 (4), 367-380.

Durand, C.P., Andalib, M., Dunton, G.F., Wolch, F., Pentz, M.A., 2011. A systematic re view of built environment factors related to physical activity and obesity risk: implications for smart growth urban planning. Obes. Rev. 12, e173-e182.

EC (European Commission), 2010. Europe 2020. A European Strategy for Smart, Sustainable and Inclusive Growth. EC, Brussels.

EC (European Commission), 2012a. Connecting Smart and Sustainable Growth Through Smart Specialisation. A Practical Guide for ERDF Managing Authorities. Publications Office of the European Union, Luxembourg.

EC (European Commission), 2012b. Guidelines on Best Practice to Limit, Mitigate or Compensate Soil Sealing (Commission Staff Working Document). EC, Brussels.

EC (European Commission), 2013. Communication from the Commission to the European Parliament, the council, the European Economic and Social Committee and the Committee of the Regions. In: Green Infrastructure (GI) - Enhancing Europe's Natural Capital. COM(2013) 249 Final. Brussels.

EEA, 2011. Green Infrastructure and Territorial Cohesion. The Concept of Green Infrastructure and Its Integration into Policies Using Monitoring Systems. Publication Office of the European Union, Luxembourg.

EEA, 2016. Urban Sprawl in Europe. Joint EEA-FOEN Report. Publication Office of the European Union, Luxembourg.

Fischer, T.B., Dalkmann, H., Lowry, M., Tennøy, A., 2010. The dimensions and context of transport decision making. In: Joumard, R., Gudmundsson, H. (Eds.), Indicators of Environmental Sustainability in Transport. Les Collections De l'Inrets, Paris, (pp. 79-102).

Frank, L.D., Schmid, T.L., Sallis, J.F., Chapman, J., Saelens, B.E., 2005. Linking objectively measured physical activity with objectively measured urban form: findings from SMARTRAQ. Am. J. Prev. Med. 28 (2), 117-125.

Galster, G., Hanson, R., Ratcliffe, M., Wolman, H., Coleman, S., Freihage, J., 2001. Wrestling sprawl to the ground: definition and measuring an elusive concept. Hous. Policy Debate 12 (4), 681-717.

Giffinger, R., Fertner, C., Kramar, H., Kalasek, R., Pichler-Milanović, N., Meijers, E., 2007. Smart Cities - Ranking of European Medium-sized Cities. Final Report. Centre of Regional Science, Vienna.

Gill, S.E., Handley, J.F., Ennos, A.R., Pauleit, S., 2007. Adapting cities for climate change: the role of the green infrastructure. Climate Change Cities 33 (1), 115-133.

Girardin, F., Vaccari, A., Gerber, A., Biderman, A., Ratti, C., 2009. Quantifying urban attractiveness from the distribution and density of digital footprints. Int. J. Spatial Data Infrastuct. Res. 4, 175-200.

Grunewald, K., Richter, B., Meinel, G., Herold, H., Syrbe, R.-U., 2017. Proposal of indicators regarding the provision and accessibility of green spaces for assessing the ecosystem service recreation in the city in Germany. Int. J. Biodivers. Sci. Ecosyst. Serv. Manage. 13 (2), 26-39.

Haaland, C., van den Bosch, C.K., 2015. Challenges and strategies for urban green-space planning in cities undergoing densification. A review. Urban For. Urban Greening 14, $760-771$.

Haase, D., Nuissl, H., 2007. Does urban sprawl drive changes in the water balance and policy? The case of Leipzig (Germany) 1870-2003. Landsc. Urban Plan. 80 (1-2), $1-13$.

Hansen, R., Pauleit, S., 2014. From multifunctionality to multiple ecosystem services? a conceptual framework for multifunctionality in green infrastructure planning for urban areas. AMBIO 43 (4), 516-529.

Hansen, R., Frantzeskaki, N., McPhearson, T., Rall, E., Kabisch, N., Kaczorowska, A., Kain, J.-H., Artmann, M., Pauleit, S., 2015. The uptake of the ecosystem services concept in planning discourses of European and American cities. Ecosyst. Serv. 12, 228-246.

Hashem, I.A.T., Yaqoob, I., Anuar, N.B., Mokhtar, S., Gani, A., Khan, S.U., 2014. The rise of Big Data on cloud computing: review and open research issues. Inf. Systems 47, 98-115.

Heink, I., Kowarik, I., 2010. What are indicators? On the definition of indicators in ecology and environmental planning. Ecol. Indic. 10, 584-593.

Hersperger, A.M., Ioja, C.I., Steiner, F., Tudor, C.A., 2015. Comprehensive consideration of conflicts in the land-use planning process: a conceptual contribution. Carpathian J. Earth Environ. Sci. 10 (4), 5-13.

Howley, P., 2009. Attitudes towards compact city living: towards a greater understanding of residential behavior. Land Use Policy 26 (3), 792-798.

Ioja, C.I., Grădinaru, S.R., Onose, D.A., Vânău, G.O., Tudor, A.C., 2014a. The potential of school green areas to improve urban green connectivity and multifunctionality. Urban For. Urban Greening 13 (4), 704-713.

Ioja, C.I., Nita, M.R., Vanau, G.O., Onose, D.A., Gavrilidis, A.A., 2014b. Using multicriteria analysis for the identification of spatial land-use conflicts in the Buchares Metropolitan Area. Ecol. Indic. 42 (1), 112-121.

Jang, M., Kang, C.-D., 2015. Urban greenway and compact land use development A multilevel assessment in Seoul, South Korea. Landsc. Urban Plan. 143, 160-172.

Jepson Jr., E.J., Edwards, M.M., 2010. 'How possible is sustainable urban development? an analysis of planners' perceptions about new urbanism, smart growth and the ecological city'. Plan. Pract. Res. 25 (4), 417-437.

Kambites, C., Owen, S., 2006. Renewed prospects for green infrastructure planning in the UK. Plan. Pract. Res. 21 (4), 483-496.

Kovács, E., Kelemen, E., Kalóczkai, Á., Margóczi, K., Pataki, G., Gébert, J., Málovics, G., Balázs, B., Roboz, Á., Kovács, E., Mihók, B., 2014. Understanding the links between ecosystem service trade-offs and conflicts in protected areas. Ecosyst. Serv. 12, $117-127$.

Krüger, T., Meinel, G., Schumacher, U., 2013. Land-use monitoring by topographic data analysis. Cartog. Geogr. Inform. 40 (3), 220-228.

Krehl, A., Siedentop, S., Taubenböck, H., Wurm, M., 2016. A comprehensive view on urban spatial structure: urban density patterns of german city regions. Int. J. Geo-Inf. 5,76 .

Kyttä, M., Broberg, A., Tzoulas, T., Snabb, K., 2013. Towards contextually sensitive urban densification: location-based softGIS knowledge revealing perceived residential environmental quality. Landsc. Urban Plan. 113, 30-46.

Larondelle, N., Lauf, S., 2016. Balancing demand and supply of multiple urban ecosystem services on different spatial scales. Ecosyst. Serv. 22, 18-31.

Lehmann, I., Mathey, J., Rößler, S., Bräuer, A., Goldberg, V., 2014. Urban vegetation structure types as a methodological approach for identifying ecosystem services -Application to the analysis of micro-climatic effects. Ecol. Indic. 42, 58-72.

Lovell, S.T., Taylor, J.R., 2013. Supplying urban ecosystem services through multifunctional green infrastructure in the United States. Landsc. Ecol. 28, 1447-1463.

Luque-Ayala, A., Marvin, S., 2015. Developing a critical understanding of smart urbanism? Urban Studies 52 (12), 2105-2116.

MEA (Millennium Ecosystem Assessment), 2005. Ecosystems and Human Well-Being, Synthesis. Island Press, London.

Marsal-Llacuna, M.-L., Colomer-Llinàs, J., Meléndez-Frigloa, J., 2015. Lessons in urban monitoring taken from sustainable and livable cities to better address the Smart Cities initiative. Technol. Forecast. Soc. Change 90, 611-622.

McPhearson, T., Pickett, S.T.A., Grimm, N.B., Niemelä, J., Alberti, M., Elmqvist, T., Weber, C., Haase, D., Breuste, J., Qureshi, S., 2016. Advancing urban ecology toward a science of cities. Bioscience 66 (3), 198-212.

Meinel, G., 2014. Sekundärstatistisches Flächennutzungsmonitoring- probleme und Lösungen. Flächenmanagement und Bodenordnung 76 (6), 274-282.

Nathan, A., Pereira, G., Foster, S., Hooper, P., Saarloos, D., Giles-Corti, B., 2012. Access to commercial destinations within the neighbourhood and walking among Australian older adults. Int. J. Behav. Nutr. Phys. Act. 9, 133.

Neuman, M., 2005. The compact city fallacy. J. Plan. Educ. Res. 25, 11-26. 
OECD, 2012. Compact City Policies. A Comparative Assessment. OECD Publishing, Paris. Oberndorfer, E., Lundholm, J., Bass, B., Coffman, R.R., Doshi, H., Dunnett, N., Gaffin, S., Köhler, M., Liu, K.K.Y., Rowe, B., 2007. Green roofs as urban ecosystems: ecological structures, functions, and services. Bioscience 57 (10), 823-833.

Oh, K., Jeong, S., 2007. Assessing the spatial distribution of urban parks using GIS. Landsc. Urban Plan. 82, 25-32.

Papa, R., Gargiulo, C., Galderisi, A., 2013. Towards an urban plannerśs perspective on smart city. TeMA 1, 5-17.

Peters, K., Elands, B., Buijs, A., 2010. Social interactions in urban parks: stimulating social cohesion? Urban For. Urban Greening 9 (2), 93-100.

Rall, E.L., Haase, D., 2011. Creative intervention in a dynamic city: a sustainability assessment of an interim use strategy for brownfields in Leipzig, Germany. Landsc. Urban Plan. 100 (3), 189-201.

Richardson, E.A., Pearce, J., Mitchell, R., Kingham, S., 2013. Role of physical activity in the relationship between urban green space and health. Public Health 127 (4), 318-324.

Rink, D., Haase, A., Grossmann, K., Couch, C., Cocks, M., 2012. From long-Term shrinkage to Re-Growth? the urban development trajectories of Liverpool and Leipzig. Built Environ. 38 (2), 162-178.

Russo, A., Escobedo, F.J., Cirella, G.T., Zerbe, S., 2017. Edible green infrastructure: an approach and review of provisioning ecosystem services and disservices in urban environments. Agric. Ecosyst. Environ. 242, 53-66.

Schwarte, C., Adebowale, M., 2007. Environmental Justice and Race Equality in the European Union. Capacity Global, London.

Scott, J.W., 2007. Smart growth as urban reform: a pragmatic 'Recoding' of the new regionalism. Urban Studies 44 (1), 1-35.

Siedentop, S., Fina, S., 2012. Who sprawls most? Exploring the patterns of urban growth across 26 European countries. Environ. Plan. A 44, 2765-2784.

Smart Growth Network, 2003. Getting to Smart Growth. 100 Policies for implementation. https://www.epa.gov/sites/production/files/2014-01/documents/gettosg.pdf (Accessed 17 March 2016).

Soares, A.L., Rego, F.C., McPhearson, E.G., Simpson, J.R., Peper, P.J., Xiao, Q., 2011. Benefits and costs of street trees in Lisbon, Portugal. Urban For. Urban Gree. 10 (2),
69-78.

Thomas, I., Frankhauser, P., Frenay, B., Verleysen, M., 2010. Clustering patterns of urban built-up areas with curves of fractal scaling behaviour. Environ. Plann. B 37 (5), 942-954.

Tian, Y., Jim, C., Tao, Y., 2012. Challenges and strategies for greening the compact city of Hong Kong. J. urban. plan. D. ASCE 138 (2), 101-109.

Tidball, K.G., Krasny, M.E., 2007. From risk to resilience: what role for community greening and civic ecology in cities? In: Wals, A. (Ed.), Social Learning Towards a More Sustainable World. Wagengingen Academic Press, Wagening, pp. 149-164.

Torre, A., Melot, R., Magsi, H., Bossuet, L., Cadoret, A., Caron, A., Darly, S., Jeanneaux, P., Kirat, T., Pham, H.V., Kolokouris, O., 2014. Identifying and measuring land-use and proximity conflicts: methods and identification. SpringerPlus 3 (1), 1-26.

Tratalos, J., Fuller, R.A., Warren, P.H., Davies, R.G., Gaston, K.J., 2007. Urban form, biodiversity potential and ecosystem services. Landsc Urban Plan. 83, 308-317.

Tudor, C.A., Ioja, C.I., Rozylowicz, L., Patru-Stupariu, I., Hersperger, A.M., 2015. Similarities and differences in the assessment of land-use associations by local people and experts. Land Use Policy 49, 341-351.

United Nations, 2012. World Urbanization Prospects. The 2011 Revision. Department of Economic and Social Affairs, New York.

Vanolo, A., 2016. Is there anybody out there? The place and role of citizens in tomorrow's smart cities. Futures 82, 26-36.

Wald, D.M., Hostetler, M.E., 2010. Conservation value of residential open space: designation and management language of florida's land development regulations. Sustainability 2 , 1536-1552.

Whitehead, M., 2012. The sustainable city: an obituary? On the future form and prospects of sustainable urbanism. In: Flint, R., Raco, M. (Eds.), The Future of Sustainable Cities: Critical Reflections. The Policy Press, Chicago, pp. 29-46.

Williams, K., Joynt, J., Hopkins, D., 2010. Adapting to climate change in the compact city: the suburban challenge. Built Environ. 36 (1), 105-115.

Wurster, D., Artmann, M., 2014. Non-monetary assessment of urban ecosystem services on site level - development of a methodology for a standardized selection, mapping and assessment of representative sites. AMBIO 43 (4), 454-465. 